\title{
A VISCOUS PROTEIN OBTAINED IN LARGE AMOUNT FROM THE SERUM OF A PATIENT WITH MULTIPLE MYELOMA
}

\author{
By SHEPARD SHAPIRO, VICTOR ROSS, AND DAN H. MOORE \\ (From the Third (New York University) Division, Welfare Hospital; the Department of \\ Medicine, New York University; and the Department of Biochemistry and the \\ Electrophoresis Laboratory, Columbia University, New York City)
}

(Received for publication July 21, 1942)

A case of multiple myeloma with hyperproteinemia has recently been observed in which there was obtained, by prolonged dialysis of the blood plasma against distilled water, a large quantity of viscous protein. The excessive quantity of this protein, and the absence of reports of a similar observation in multiple myeloma, with the exception which will be discussed below, makes a record of the circumstances under which it was obtained of interest.

\section{REPORT OF CASE}

A 57-year-old, white, unmarried, female musician commenced to lose weight and grow weak in October of 1941. Later, she developed continuous, dull pains across the back, in both shoulder regions and along the spine. On several occasions, she observed vaginal staining. The familial and past histories were not significant. The menopause had occurred about 7 years previously and was uneventful.

On examination January 12, 1942, waxy pallor was noted. The skin was loose throughout and of poor tone. Edema was not present. On the seventh rib, at about the posterior axillary line, there was a tender swelling approximately the size of a walnut and attached to bluish discolored skin. This mass was not movable and was firm in consistency. The lungs were clear, the heart rate was about 90 per minute, of regular rhythm with an occasional premature contraction. A soft, blowing, systolic murmur was heard over the apex of the heart. The blood pressure was 100/60. No masses were felt on palpation of the abdomen nor was the liver or spleen enlarged. The extremities showed evidences of wasting and the deep reflexes were hypoactive. Pelvic examination did not reveal any infiltration in the parametrium or signs of bleeding.

The patient grew progressively weaker. On January 31, 1942, numerous moist râles were heard over both bases. A firm and deeply attached, somewhat tender prominence had appeared over the fourth dorsal vertebra. Oozing of blood from the gums, and, on several occasions, grossly bloody urine were observed. In addition, during the second week in February, numerous purpuric spots appeared in the skin and larger hematomata over areas of friction. A positive capillary fragility test was observed at the same time. The patient died on March 8, 1942. Roentgen films showed generalized osteoporosis with punched out areas of rarefaction. A diagnosis of multiple myeloma was made and confirmed by the biopsy obtained just before death from the mass over the rib.

\section{LABORATORY FINDINGS}

On January 13, 1942, the hemoglobin was 4.2 grams per $100 \mathrm{ml}$. blood; the red cell count was $1,408,000$ and the leukocyte count 10,250, of which segmented neutrophiles comprised 55 per cent, non-segmented 12 per cent, monocytes 1 per cent, lymphocytes 30 per cent, and metamyelocytes 2 per cent. The blood sugar was $108 \mathrm{mgm}$., N. P. N. $38 \mathrm{mgm}$., cholesterol $329 \mathrm{mgm}$. (of which esters comprised 64 per cent), inorganic phosphorus $4.2 \mathrm{mgm}$., calcium $12 \mathrm{mgm}$., and phosphatase 2.2 Bodansky units per $100 \mathrm{ml}$. blood. The total serum protein was 9.3 grams per cent, of which albumin comprised 3.0 and globulin 6.3 grams per cent. The hematocrit was 16 per cent. The urine was repeatedly negative for Bence-Jones protein.

It was repeatedly noted that immediately after blood was withdrawn by venipuncture, the cellular portion quickly settled to the bottom and the supernatant fluid clotted. This may have been an expression of the pseudoagglutination mentioned by Magnus-Levy (1) and by von Bonsdorff, Groth and Packalén (2). There was no retraction of the clot, centrifugation being necessary in order to obtain serum.

Prothrombin estimations using snake venom [Shapiro, Sherwin, Redish and Campbell (3)] yielded the following values :

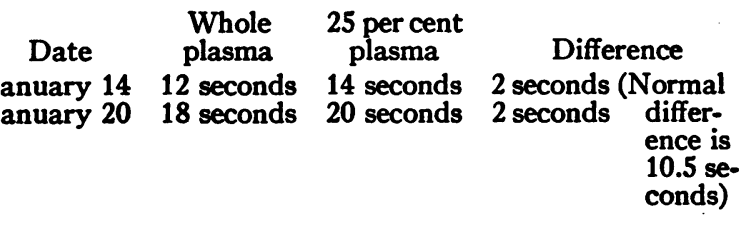

Later these were repeated and revealed the following figures, using rabbit brain thromboplastin-calcium chloride mixture (3) instead of snake venom:

$\begin{array}{ccc}\text { Date } & \text { Whole plasma } & 12.5 \text { per cent plasma } \\ \text { February 20 } & 33 \text { seconds } & 32 \text { seconds } \\ \text { February 27 } & 51 \text { seconds } & 40 \text { seconds }\end{array}$

In both series of estimations, the difference in prothrombin time between whole and diluted plasma is

\footnotetext{
1 Normal value for whole plasma is 24 seconds.

2 This is normal value for this dilution of plasma.
} 

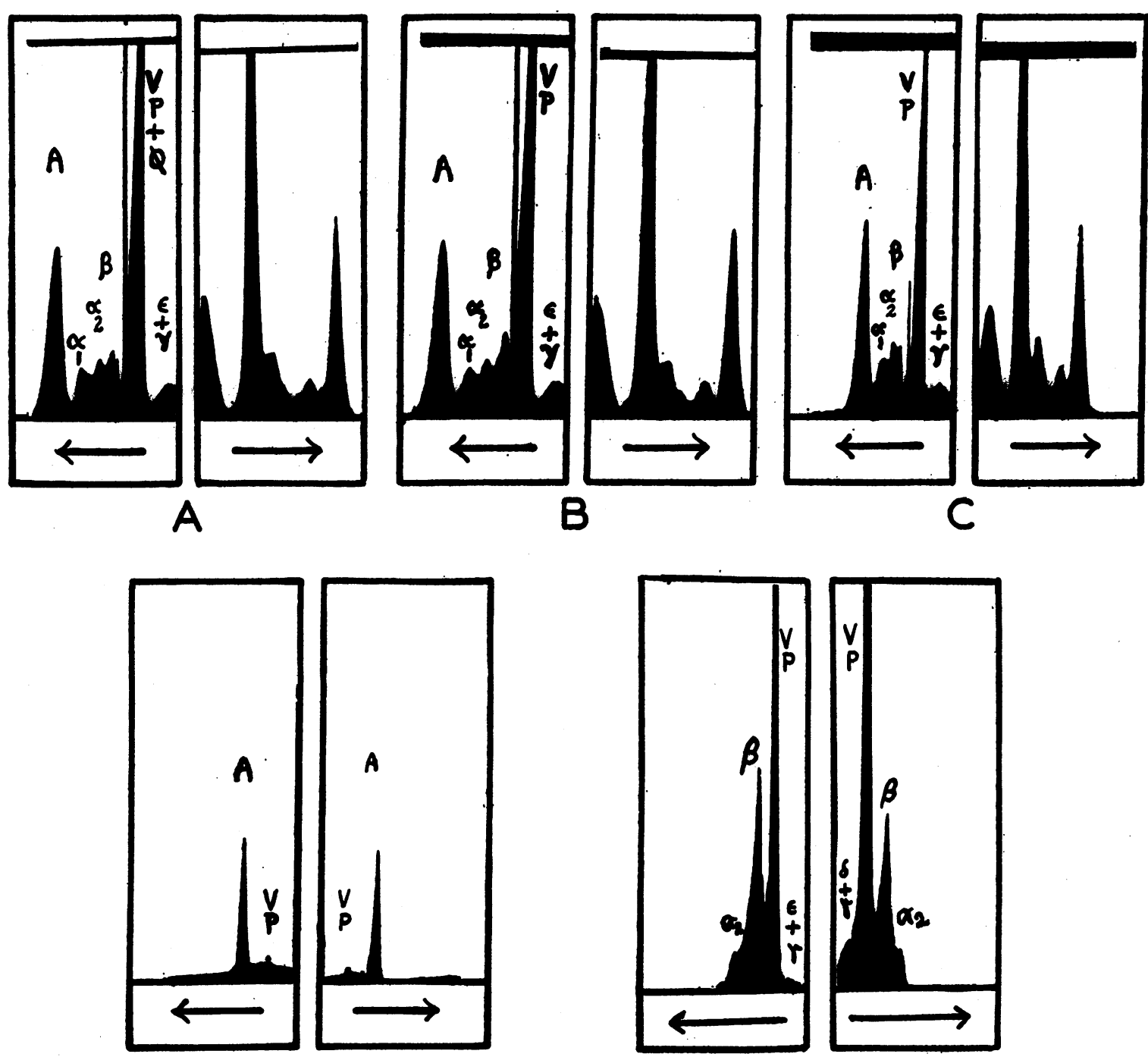

D

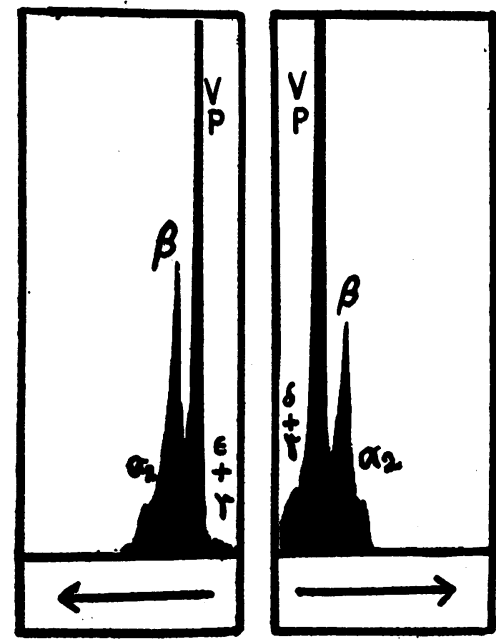

5

Fig. 1. Electrophoretic Patterns of the Patient's Plasma and Serum, of the Fluid Above the Viscous Layer, and of the Viscous Prectpitate

Pictures of the descending limb of the electrophoresis cell are indicated by arrows pointing to the left; those of the ascending limb by arrows pointing to the right. The sharp boundary seen between $\beta$ globulin and the VP protein in the patterns of the descending limb is the so-called $\beta$ anomaly. The Toepler schlieren method with Longsworth's scanning modification was used to obtain the patterns. A potential gradient of 8.2 volts per $\mathrm{cm}$. was employed in the barbiturate experiments (Figures 1A, 1B, and 1C) and 3.9 volts per $\mathrm{cm}$. in the phosphate experiments (Figure 1D and 1E).

The current in experiments illustrated in Figures 1A, 1B, and 1C was 12 milliamperes and the conductivities of the fluids were $0.00188,0.00187$, and 0.00199 mhos. The current in the experiment illustrated in Figure ID was 30 milliamperes and the conductivity 0.00989 mhos. The current in the experiment illustrated in Figure 1E was 14 milliamperes and the conductivity 0.00938 mhos. The duration of the electrophoresis was $11 / 2$ hours in Figures 1A, 1B, and 1D and 1 hour and 1 minute in Figure 1C and 2 hours in Figure 1E. Composition, $\mathrm{pH}$ and ionic strengths of the buffers used are given in Table I. 
markedly reduced-in fact, in the second series, the plasma diluted to 12.5 per cent yielded a shorter prothrombin time than the whole plasma. This phenomenon, according to the interpretation suggested by Shapiro et al. (3), is indicative of an excess of anticoagulant in the blood. These findings are not believed to bear any direct relation to the protein described below. It is noteworthy that the cutaneous hemorrhages were first observed at about the time that the prolongation of the prothrombin time of the whole plasma was observed. This is the subject of another study and will be discussed in a subsequent publication.

The electrophoretic pattern of the blood plasma of this patient is shown in Figure 1A. In addition to the peaks representing albumin, and $\alpha, \beta$, and $\gamma^{8}$ globulins with mobilities comparable to those given by Moore and Lynn (4) for these components in normal serum, there is a component having a mobility of $-4.2 \times 10^{-6} \mathrm{~cm}$. per second, per volt, per $\mathrm{cm}$. ( $\alpha_{2}$ globulin in Table I), which is intermediate between the mobilities of $\alpha$ and $\beta$ globulins.4 More striking, however, is the very large peak, marked VP, with a mobility of -1.9 . Figure $1 B$ shows a pattern of the patient's serum. The VP peak is present in apparently undiminished size, proving that the component is not fibrinogen. Furthermore, only 0.5 per cent of fibrinogen was found in the blood plasma. Figure 1C shows the pattern of the blood plasma after removal of the precipitate formed by adding enough solid $\mathrm{NaCl}$ to make the concentration 25 per cent. The extra protein is still present. Mobilities, calculated from the descending limbs of these patterns, are given in Table I. Measurements of the area under the VP peak of several patterns show that this component is present to the extent of about 45 per cent of the total serum protein.s If one adds the VP protein to the globulins, one obtains an albumin to globulin ratio of $0.34,0.37$, and 0.36 respectively for the three patterns of plasma and serum shown in Figure 1. Omitting the VP from such a calculation yields ratios of $0.92,1.05$, and 0.90 .

A solution of the VP protein purified by electrophoresis (in $0.02 \mathrm{M}$ phosphate buffer of $\mathrm{pH} 7.5$ and containing $0.15 \mathrm{M} \mathrm{NaCl} ; \mu=0.2$ ) became cloudy when heated to $58^{\circ}$ in the water bath. At $60^{\circ} \mathrm{C}$, it became somewhat

8 The $\gamma$-globulin peak contains also that due to the buffer boundary. Since the ratio of protein concentration to buffer ionic strength is rather high in these analyses of whole plasma and serum, the salt boundary is large. The true $\boldsymbol{\gamma}$-globulin peak is somewhat masked by the "false" peak giving erroneous positive mobilities $(+0.3,+0.2,+0.2$ respectively in Figures $1 \mathrm{~A}, 1 \mathrm{~B}$ and 1C) for $\gamma$-globulin.

- See the article by Longsworth, L. G., Chem. Rev., $1942,30,323$, for evidence of a component separating from albumin in normal human plasma in barbiturate buffer, $\mathrm{pH} 8.6$.

${ }^{5}$ For Figure $1 \mathrm{~A}, \mathrm{VP}=45$ per cent, albumin $=26$ per cent, $a_{1}=6$ per cent, $a_{2}=6$ per cent, $\beta=11$ per cent, and $\gamma=6$ per cent.
TABLE I

Electrophoretic mobilities of the blood proteins, in $\mathrm{cm}$. per second per volt per $\mathrm{cm} . \times 10^{-6}$

\begin{tabular}{|c|c|c|c|c|c|c|c|}
\hline $\begin{array}{l}\text { Fig- } \\
\text { ure }\end{array}$ & $\begin{array}{l}\text { Material in } \\
\text { the cell }\end{array}$ & pH & $\underset{\text { bumin }}{\text { Al- }}$ & $\begin{array}{c}\alpha_{1} \\
\text { Glo- } \\
\text { bulin }\end{array}$ & $\begin{array}{c}\alpha_{2} \\
\text { Glo- } \\
\text { bulin }\end{array}$ & $\begin{array}{c}\text { Glo- } \\
\text { bulin }\end{array}$ & $\begin{array}{c}\text { VP } \\
\text { Pro- } \\
\text { tein }\end{array}$ \\
\hline $\begin{array}{l}1 \mathrm{~A} \\
1 \mathrm{~B} \\
1 \mathrm{C}\end{array}$ & $\begin{array}{l}\text { Plasma* } \\
\text { Serum* } \\
\mathrm{NaCl}^{*} \\
\text { treated } \\
\text { plasma }\end{array}$ & $\begin{array}{l}7.8 \\
7.8 \\
7.8\end{array}$ & $\begin{array}{l}-6.7 \\
-6.7 \\
-7.0\end{array}$ & $\begin{array}{l}-5.1 \\
-5.1 \\
-5.1\end{array}$ & $\begin{array}{l}-4.2 \\
-4.0 \\
-4.3\end{array}$ & $\begin{array}{l}-3.4 \\
-3.1 \\
-3.5\end{array}$ & $\begin{array}{l}-1.9 \\
-1.9 \\
-1.7\end{array}$ \\
\hline In & $\begin{array}{l}\text { Supernate of } \\
\text { viscous } \\
\text { protein } \dagger\end{array}$ & 7.4 & -5.4 & $?$ & & & -1.9 \\
\hline IE & $\begin{array}{l}\text { Viscous } \\
\text { protein } †\end{array}$ & 7.3 & & & -3.9 & -3.3 & -1.9 \\
\hline
\end{tabular}

* Serum and plasma were diluted 1 to 4 with a buffer consisting of $0.025 \mathrm{M}$ lithium diethylbarbiturate, $0.025 \mathrm{M}$ diethylbarbituric acid, and $0.025 \mathrm{M}$ lithium chloride $(\mu=0.05)$, and dialyzed against 1 liter of the same buffer for 1 day and then against 2 liters the second day. Except for $\gamma$ globulin, all the components carried a negative charge under these conditions. See Footnote 3 .

† Carried out in the same way as serum and plasma experiments but in $0.02 \mathrm{M}$ phosphate buffer containing $0.15 \mathrm{M} \mathrm{NaCl}(\mu=0.2)$. Mobilities calculated from an electrophoretic pattern of the serum in phosphate buffer were: albumin 5.4, $\alpha$ globulin 3.3, ( $\alpha_{1}$ and $\alpha_{2}$ globulin were unresolved in the descending limb), $\beta$ globulin 2.5, VP 1.7, and $\gamma$ globulin 0.1 . Mobilities were calculated from the patterns of the descending limb.

viscous. The viscosity increased as the temperature was raised till at $67^{\circ} \mathrm{C}$., it was very viscous, and at $72^{\circ} \mathrm{C}$., the protein was completely coagulated. When the temperature was raised to $100^{\circ} \mathrm{C}$., solution did not occur. It, therefore, was not Bence-Jones protein. The sedimentation constant, measured in the air driven ultracentrifuge (5), was $7.0 \mathrm{~S}$ and the diffusion constant $4.06 \times 10^{-5}$, corrected to $20^{\circ} \mathrm{C}$. The calculated molecular weight is 162,000 , thus further excluding Bence-Jones protein. A solution of the protein, containing 1 part in 100,000 , yielded a precipitate with rabbit anti-human serum at room temperature. Greater dilutions were not tried.

When the untreated blood plasma was dialyzed in viscose sausage casing against repeated changes of distilled water in the ice box (ca. $2^{\circ} \mathrm{C}$.), there formed, after about 10 days, a sharply demarcated layer of liquid at the bottom of the bag which increased in quantity until, after several days, it amounted to about 15 per cent of the total volume. This layer was translucent, had a marked greenish tint, and was so viscous that it was difficult to remove from the bag. In order to determine the relation of this viscous protein material ${ }^{\circ}$ to the VP

- By the term "viscous protein," we do not mean that the precipitate is composed of a single molecular species, nor do we use the term to describe the behavior of the precipitate in dilute solution. The term is used to describe the gross appearance of the excessively gelatinous and sticky material. Under identical conditions, plasmas of several hospital patients yielded what appeared to be 
peak in the electrophoretic patterns of serum and plasma, a pattern of the fluid above the viscous layer in the dialysis bag was made after removal of some solid protein. The result is shown in Figure 1D. Only a very small amount of the VP protein is present. The large peak seen in the pattern represents albumin. The small peak has the mobility of the VP protein. There is also a small quantity of $\alpha_{1}$ globulin (seen more clearly in the original picture). It is believed, therefore, that the viscous protein is derived from the protein represented by the VP peak seen in the serum and plasma patterns. There is reason to believe, however, that they are not identical. For example, when the electrophoretically isolated V.P component was dialyzed against water to free it of salts, partial precipitation occurred, but the precipitate was not viscous. Also the electrophoretically prepared protein (mobility - 1.9) possessed a higher coagulation temperature than the viscous protein.

A pattern of the viscous precipitate, ${ }^{7}$ following removal of some water-insoluble protein resting on its surface and repeated washing with water, is shown in Figure 1E. The VP protein is present, together with $a_{2}$ and $\boldsymbol{\beta}$ globulin and possibly some $\boldsymbol{\gamma}$ globulin. Below we present reasons for suggesting that the viscous protein represents a complex of the VP protein as seen in the patterns of the serum and plasma with another serum protein, or proteins, which forms on removal of salts. If this is so, then the presence of the $a_{2}$ and $\beta$ globulin peaks in the pattern $1 \mathrm{E}$ indicate a dissociation of the complex in the presence of the salts comprising the buffer. There is, of course, the possibility that the $\alpha_{2}$ and $\beta$ globulins seen in Figure $1 \mathrm{E}$ represent the water-insoluble fractions of these two proteins, co-existing with the VP protein.

When a little of the viscous protein was drawn out into a thread, it had a pearly sheen. It dissolved readily in $\mathrm{N} / 50 \mathrm{HCl}$ and $\mathrm{N} / 50 \mathrm{NaOH}$ and in 0.87 per cent $\mathrm{NaCl}$, yielding limpid solutions. When a solution of the viscous material in saline was heated to $55^{\circ} \mathrm{C}$., it became turbid. Raising the temperature to $64^{\circ} \mathrm{C}$. precipitated the protein. Further heating to $100^{\circ} \mathrm{C}$. did not cause resolution. A solution of the viscous protein gave the usual protein color tests. The Molisch test was positive also. A heavy precipitate resulted on the addition of $\mathrm{HNO}_{3}$, trichloracetic and phosphotungstic acids with potassium ferrocyanide and potassium picrate in the presence of acetic acid. Acetic acid alone did not precipitate the protein. The viscous protein (dried at $100^{\circ}$ C. vacuum and $\mathrm{P}_{2} \mathrm{O}_{3}$ ) contained 13.9 per cent nitrogen. Following hydrolysis with $\mathrm{N} / 1 \mathrm{HCl}$ at $100^{\circ} \mathrm{C}$. in a sealed tube for 4 hours, there was found 13.4 per cent ${ }^{8}$ reducing substances (as glucose) by the Hagedorn-Jensen method.

on close inspection very small quantities of semi-liquid material along with the usual precipitate of globulin.

7 This precipitate was obtained by dialysis of a second sample of blood plasma.

8 This figure is probably higher than the true value owing to the reducing action of certain amino acids formed by hydrolysis.

\section{DISCUSSION}

In multiple myeloma, the extra protein in the serum may differ from case to case. In many instances it is a euglobulin, in some it is one of several kinds of Bence-Jones protein, while in others it has not been classified. Instances of the last are the protein of von Bonsdorff, Groth and Packalén (2), discussed below, and the viscous protein described in this report. Magnus-Levy classified the extra protein in some of his multiple myeloma cases as euglobulin because of its precipitation on dilution of the sera with water. In an extensive study, Gutman et al. (6) found that in many cases of hyperglobulinemia in multiple myeloma, the increment consisted of either euglobulin or pseudoglobulin 1, as described by the Howe salting-out method. In the case here described, the excess globulin behaved as pseudoglobulin 2, being precipitated out of the serum on the addition of 30 volumes of $1.5 \mathrm{M} \mathrm{Na} \mathrm{SO}_{4} .^{\circ}$

Multiple myeloma sera may show variations in their electrophoretic patterns also. Longsworth, Shedlovsky, and MacInnes (7) demonstrated a considerably enlarged $\beta$ globulin peak, while Kekwick's (8) patterns indicate a greatly increased amount of $\gamma$ globulin in several cases and a large increase in $\beta_{2}$ globulin in one instance. (The latter has a mobility between $\beta$ and $\gamma$ globulins.) It is interesting that precipitation of the last serum in phosphate buffer $\mathrm{pH} 8, \mu=0.1$, with 20 per cent $\mathrm{Na}_{2} \mathrm{SO}_{4}$, yielded a sticky product, electrophoretically homogeneous ${ }^{10}$ at every $\mathrm{pH}$ investigated, but showing four components in the ultracentrifuge. The carbohydrate: $\mathrm{N}$ ratio of the globulin so precipitated was 0.167 , while that of the globulin prepared from one of the other sera was 0.083 . The isoelectric points of the globulins he prepared from the myelomatous sera differed markedly from that of normal human $\gamma$ globulin, being ca. 6.5 for the latter and ca. 7.0 for $\gamma$ globulin in each of 2 of the former, and $c a .5 .8$ for the $\beta_{2}$

9 We are indebted to Dr. A. B. Gutman for this determination. He found the total protein to be 10.5 grams per cent. Of this, the albumin comprised 2.9 grams per cent, and globulin 7.6 grams per cent. The latter was composed of 0.8 per cent pseudoglobulin 1, 6.5 per cent pseudoglobulin 2 , and 0.3 per cent euglobulin.

10 The mobility of the $\beta_{2}$ globulin, electrophoretically separated from the corresponding serum, was -1.40 at pH 7.99 phosphate buffer, with $\mu=0.1$. 
globulin he observed in one of the cases. Gutman and his co-workers found, in a larger series, that the hyperproteinemia in multiple myeloma may be associated with increased quantities of protein possessing the mobility of either $\beta$ or $\gamma$ globulin or intermediate between them.

A protein resembling, in certain of its properties, the one we have described was observed by von Bonsdorff, Groth and Packalén in the serum of a patient with multiple myeloma. It was viscous and crystallizable, and it coagulated when its solution was heated to $71^{\circ} \mathrm{C}$. It was insoluble in water and physiological salt solution but was soluble in weak alkali and weak acid. Its nitrogen content is given as $\mathbf{1 3 . 8}$ per cent of an incompletely dried sample. No data are given for its carbohydrate content. They report a sedimentation constant $\mathrm{S}_{20}=7.1 \times 10^{-18}$ and a molecular weight of 200,000 . In its viscosity and its solubility in weak alkali and weak acid. and possibly in its nitrogen content, their protein resembles the viscous protein described here. Its insolubility in $\mathrm{NaCl}$ solution, its coagulation temperature and serological behavior ${ }^{11}$ make it appear different. The serum of their patient also behaved differently from that which we studied in that it $(a)$ clotted at $71^{\circ} \mathrm{C}$., (b) separated into two layers after several hours in the ice-box, and (c) deposited crystals of their protein after 48 hours. Our plasma failed to separate into layers even after many weeks in the ice-box; a flocculent sediment formed. We did not observe crystal formation.

A viscous protein has been observed by several investigators in normal human and horse serum. Piettre (9) identified a viscous protein in normal human serum which he named myxoprotein. Arcand (10) measured the amount of this protein in normal and pathological body fluids. Doladilhe (11) and Ho Dac An (12) also have reported that a viscous protein separates on dialyzing horse and human sera.

Of considerable interest in regard to the viscous protein herein described is the work of Hewitt (13). This investigator found that, following initial precipitation of protein (euglobulin 1) resulting on dialysis of normal horse and human sera against water, there forms, on extended

11 See the recent report of further serological examination of their protein: Packalén, T., Acta Path. et Microbiol. Scandinav., 1940, 17, 263. dialysis, a precipitate which is semi-liquid, greenish blue in color, and soluble in dilute salt solution (euglobulin 2 in his nomenclature). ${ }^{12}$ This description so well fits our viscous protein that it suggests the possibility that the extra protein VP, with the mobility of -1.9 , may react with another serum protein to yield the viscous protein herein described. The differences between the VP protein seen in the patterns of serum and plasma and the viscous protein separating on prolonged dialysis have already been mentioned. In addition, it may be added that Figure 1D shows the absence of $\beta$ and $\gamma$ peaks, suggesting that the water soluble portions of these two globulins may have been the ones combining with the VP protein to yield the viscous protein.

\section{SUMMARY}

A very large amount of viscous protein separated on prolonged dialysis, against distilled water, of the blood plasma from a patient with multiple myeloma. It contained 13.9 per cent nitrogen and, following hydrolysis, yielded 13.4 per cent reducing substance (as glucose). It coagulated at $64^{\circ} \mathrm{C}$. Solubility and precipitation characteristics are given.

Electrophoretic examination of the plasma and serum showed a very large peak with a mobility of $-1.9 \times 10^{-5} \mathrm{~cm}$. per second per volt per $\mathrm{cm}$. (barbiturate buffer, $\mathrm{pH}=7.8, \mu=0.05$ ). This material had a molecular weight of 162,000 . It coagulated at $72^{\circ} \mathrm{C}$. and did not redissolve when the temperature was raised to $100^{\circ} \mathrm{C}$. It is neither fibrinogen nor Bence-Jones protein. There is some evidence to suggest that it is a normal serum globulin which reacts with another serum component to yield the viscous protein which settles out on freeing the blood plasma of salts by dialysis.

We wish to thank Miss Helen Sikorski for performing the diffusion and electrophoresis experiments. We are indebted to Dr. J. B. Weiss (Hospital for Joint Diseases) for permission to study this case. We are greatly indebted to Dr. A. E. Severinghaus for the use of his airdriven ultracentrifuge.

12 Hewitt finds that by mixing pseudoglobulin A (by which he designates the fraction of water-soluble globulin precipitated by $1 / 3$ saturation with ammonium sulfate) with his "globoglycoid" he obtains a precipitate of euglobulin 2, semiliquid in consistency, which presumably is the same as he obtains on prolonged dialysis of serum. 


\section{BIBLIOGRAPHY}

1. Magnus-Levy, A., Multiple Myelome. VII. Euglobulinämie. Zur Klinik und Pathologie. Amyloidosis. Ztschr. f. klin. Med., 1933, 126, 62.

2. von Bonsdorff, B., Groth, H., und Packalén, T. Ueber Hyperprotinämie und damit zusammenhangence Phànomene beim Myelom. Acta med. Scandinav., 1938, Supp. 89, 347.

On the presence of a high-molecular, crystalyzable protein in blood serum in myeloma. Folia haemat., 1938, 59, 184.

3. Shapiro, S., Sherwin, B., Redish, M., and Campbell, H. A., Prothrombin estimation. A procedure and clinical interpretations. Proc. Soc. Exper. Biol. and Med., 1942, 50, 85.

4. Moore, D. H., and Lynn, J., Electrophoretic measurements on normal human plasma. J. Biol. Chem., 1941, 141, 819.

5. Chiles, J. A., Jr., and Severinghaus, A. E., Hormone studies with the ultracentrifuge III. An application of Toepler's schlieren method to the analytical ultracentrifuge. Rev. Scient. Instruments, 1940, 11, 71.
6. Gutman, A. B., Moore, D. H., Gutman, E. B., McClellan, V., and Kabat, E. A., Fractionation of serum proteins in hyperproteinemia with special reference to multiple myeloma. J. Clin. Invest., 1941, $20,765$.

7. Longsworth, L. G., Shedlovsky, T., and MacInnes, D. A., Electrophoretic patterns of normal and pathological human blood serum and plasma. J. Exper. Med., 1939, 70, 399.

8. Kekwick, R. A., The serum proteins in multiple myelomatosis. Biochem. J., 1940, 34, 1248.

9. Piettre, M., Archiv do Inst. Vital, Brazil, 1922, tome 1, fasc. 1, ibid., tome II, fasc. 2, 1923. Quoted by Arcand.

10. Arcand, A., Les Protéines des Humeurs. Libraire le François, Paris, 1930.

11. Doladilhe, M., Sur la dissociation de la globuline en deux constituants : La proteine visqueuse et l'homoglobuline. Compt. rend. Soc. d. biol., 1937, 125, 409.

12. Ho Dac An, Thesis, Paris, 1933. (We have been unable to obtain a copy of this thesis.)

13. Hewitt, L. F., Serum proteins in normal and pathological conditions. Biochem. J., 1938, 32, 1540. 